\title{
TECHNOLOGICAL DETERMINISM IN CANADIAN TELECOMMUNICATIONS: TELIDON TECHNOLOGY, INDUSTRY AND GOVERNMENT
}

\author{
Donald J. Gillies \\ Ryerson Polytechnical Institute
}

\begin{abstract}
This paper looks at the notion of technological determinism as popularly used by government and industry to generate acceptance of and demand for innovation and its products. In particular, it considers how the rhetorical surround of the research, development and marketing of Telidon may be seen as technological determinism shaping communications policy.

Ce document étude la notion du déterminisme technologique tel qu'employé généralement par le gouvernement et l'industrie afin de générer une acceptation et une demande pour l'innovation et ses dérivés. Il s'attache particulièrement au cadre rhétorique de la recherche, au developpement et au marketing de Telidon pour les envisager comme un indicateur du déterminisme technologique qui façonne la politique des communications.
\end{abstract}

\section{INTRODUCTION}

\section{Telidon: Videotex and Teletext}

This paper ${ }^{1}$ has its origins in research carried out in 1981 and 1982 for the Canadian Government's Department of Communications (DOC). In particular, its Social and New Services Policy Division was trying to come to terms with the rapid changes in informatics and telematics, for instance, fibre optics, direct broadcast satellites, transborder data flows and, most important, by virtue of its celebrity, Telidon. The DOC produced a series of speeches and studies with 
such titles as National Information Technology in the Global Marketplace (Juneau, 1981), Communication and Culture (Foote, 1980), The Information Revolution and its Implications for Canada (Serafini and Andrieu, 1981), Social Aspects of Videotex Services: Proposed Policy Directions (Plowright, 1980) and Telecommunications and Canada (Clyne, 1979) ${ }^{2}$. The media and the popular imagination were subject to the rhetoric of technological change, with Telidon as its eponym, from August 1978 until March 1985, the period of Telidon's public life. This paper examines the notion of technological determinism as it surrounds technological change in a deconstructive vein: the language and attitudes of determinism, it will be suggested, are embedded in our culture and so are virtually invisible to us. This cultural embedding encourages the application of deterministic rhetoric to processes of technological change by interested agents of that change. Telidon provides the opportunity to probe these issues.

\section{The Information Explosion}

The developed world was experiencing in the 1970 s what came to be called the "information explosion." Popular examples that caught public attention were communication satellites, microcomputers and citizens' band radio. Canada was well placed to participate in this boom.

Telephones - In an area almost the size of Europe, Canada had on-demand telephone service and ranked fourth in the world in the number of telephones per capita.

Television - Two national English television networks and one French, as well as regional networks.

Radio - English and French A.M. and F.M. national networks, as well as several regional networks.

Communication satellites - Canada produced the world's first geostationary domestic satellite communications system which provides television, radio, telephone and data services to virtually the whole country.

Microwave - Two transcontinental microwave networks.

Data transmission - Since 1973, Canada has had transcontinental digital data transmission networks.

Packet switching - Since 1977 there have been two transcontinental packetswitched networks.

Cable television - Cable television was then available to some 75 percent of Canadian households.

Of course, Canada was not alone in trying to decide how to react to the information explosion. All the developed countries were experiencing the process 
of confronting the potential changes associated with the new information technologies. The evidence abounds, and the term "information explosion" quickly became a commonplace.

\section{Policy-Making on New Communications Technology}

Within the DOC, the Social and New Services Policy Division of the Broadcasting and Social Policy Branch was responsible for issue analysis and research towards policy development on new communication technologies and services. This research was designed to make clear "the linkage between individuals and cultures on the one hand and the new technologies and services on the other" (Foote, 1980:37). Further, "the Division's principal mandate [was] to foster a positive social adaptation to altered technological and economic realities" (Foote, 1980:4). This Division's responsibilities in the public policy process therefore encompassed the individual Canadian at one end of the spectrum and the nation itself at the other. It was committed to preparing "the intellectual groundwork" (Foote, 1980:8) of policy development to try to avoid "technological determinism and social inequalities in the extent, rate and conditions of media diffusion" (Foote, 1980:1). Evidently some middle-level officials of the DOC were at least aware of the existence of technological determinism as a possible concomitant of technological innovation.

\section{Technology, Communications Systems and Culture}

It is a scholarly theory and a social axiom to say that communication is culture, and that knowing a culture requires knowing its systems and media of communication. "Culture is defined by communication systems [and] since culture is a system of shared beliefs, attitudes, values and behaviour, then clearly there is a communication medium involved. Conversely, where there is a communication system...the users will in some measure constitute a culture" (Ferguson and Ferguson, 1980:4). The phrase used at the time by Pierre Juneau, then Deputy Minister of Communications, to acknowledge this marriage of culture and communication was "the nation's cultural delivery system" (Juneau, 1981). (He was shortly to become President of the Canadian Broadcasting Corporation, 1982-89.) The position paper for the DOC, Communication and Culture (Foote, 1980), cited above, reviewing definitions of culture, concluded "that cultural boundaries are indeed extensive and diffuse, and envelop not only man's spiritual and cognitive selves, but his science and technology as well" (Foote, 1980:2). In dealing with communication technology and culture the position paper reminded the DOC of the enduring debate on the dominance of communication by culture as against culture by communication and thus raised the issue of determinism, cultural or technological. 


\section{Media and Canadian Culture}

Canadian communication media have regularly had assigned to them a central responsibility for providing, preserving, strengthening, enriching and enhancing the country's cultural life, both historically and currently: the Minister of Communications at this time supported this pattern of attribution when he said, "We are at a critical moment in Canadian history. We can use our technology to foster and develop a vibrant culture in this nation, or we can allow the technology to vanquish the dreams of generations of Canadians" (Fox, 1981:16).

We can perceive here a potential conflict within the DOC: on the one hand, the Minister of Communications - the politician-affectively provides the simplistic dilemma of technology-driven utopia or disaster, while, on the other hand his departmental officials write of rational analysis and control of technological change. This state of affairs is very reminiscent of the setting and rhetoric in which technological determinism is debated, as I will go on to show.

\section{The Case of Telidon}

Telidon's birth was announced in Ottawa in August 1978. Federal government financing of Telidon research and development ended in March 1983. It never became a service, as videotex or teletext. (In 1988 Bell Canada began a videotex trial in Montreal, "Alex", using Canadian post-Telidon North American Presentation Level Protocol Syntax [NAPLPS] software and French hardware. It has announced plans for a service in Toronto in 1990.)

\section{Videotex and Teletext: a Brief Description}

Both videotex and teletext present information on the screen of an adapted television receiver.

Videotex is an interactive closed-circuit system which allows the user to select, in his home, office, school or other site, a "page", i.e., a full television screen, of information stored in central computerized data banks. This choice and the information chosen each flow through the switched telephone network.

Teletext is a one-way transmission system broadcast as a television signal using an invisible unused portion of existing television signals-the Vertical Blanking Interval. (These signals can be seen by tuning in any TV channel, adjusting the vertical hold control and "lowering" the image so that you can see the gap between the two frames. The 22-line space of the vertical blanking interval will then be clearly visible.) Videotex and teletext may have a common data base or separate data bases. In both cases the kinds of information available are quite varied-popular, journalistic, professional, academic, businessdirected, commercial, statistical, personal-and may include confidential data accessible only to designated "closed user groups," e.g., doctors, lawyers, social workers, banks. This content is made available by "information providers." 


\section{The Origination of Videotex and Teletext}

The origination of videotex and teletext turns on the work carried out in the field of interactive computer graphics beginning in 1949. Research and development took place in the United Kingdom, France and Canada between 1969 and 1978, with demonstrations of the technology in 1971 in the United Kingdom, in 1974 in France, and in 1978 in Canada.

In August 1978, Telidon was announced and a four-year development program began. The essence of the Telidon system is described by its originators.

Organizations in a number of European countries are promoting standards for videotex systems based on an alphamosaic approach which limits the resolution of graphic images to a format far below the resolution capabilities of the display medium. With this approach, the future development of videotex systems will be constrained, because images at the information source are described in a terminal-dependent manner with the same alphamosaic format used for their displays. Once this format is adopted it will be difficult, if not impossible, to update information source files in a manner suitable for both present and future, most advanced, videotex terminals.

A new terminal-independent method of describing images is suggested in this report on the Canadian Telidon system. Images are described as either alphageometric or alphaphotographic images by means of Picture Description Instructions (PDIs). This new approach permits the growth of large information bases, through terminal independence, which would not have to change to accommolate new developments and improvements as new technologies become available in the foreseeable future (Bown et al., 1978).

The rhetoric here, couched in technological terms, is that of the anticipated future improvements as inevitable, natural and desirable.

Some essential points in Telidon's life are:

January 1980: Telidon teletext trial begins;

May 1981: Telidon videotex Bell Canada "Vista" trial begins;

September 1982: Telidon teletext $\mathrm{CBC}$ "Project IRIS"3 trial begins;

March 1983: DOC ends Telidon R and D;

March 1984: "Project IRIS" ends;

March 1985: DOC ends Telidon exploitation operations. 


\section{The Implementation of Videotex and Teletext, including Telidon}

At the time the Canadian govemment's Telidon $\mathrm{R}$ and D program ended in March 1983, there were 115 videotex and 32 teletext applications operational in 25 countries.

Despite this large number of videotex and teletext applications, the only ones still in significant operation are in France, the U.K., some other European countries and Japan. The Telidon systems, enhanced as videotex to NAPLPS and as teletext to the North American Broadcast Teletext Standard (NABTS) have almost disappeared from the public domain of interactive computer graphics services. Private commercial applications are in operation, but the grandiose predictions of mass use made in the late 1970s and early 1980 s have come to naught. The most common practice in discussing Telidon (as it will always be thought of in popular parlance) is to describe it as "a solution looking for a problem" or "a technology looking for a market." The senior official at the DOC at the time of Telidon said in 1986 that the problem with Telidon was a failure of imagination on the part of the Canadian business community (Ostry, 1986).

Videotex in Canada came to its end in March 1985. In the United States, the "Viewtron" Telidon service of the Videotex Corporation of America ended in March 1986, as did the "Gateway" Telidon service of Videotex America.

As for teletext, the Canadian Broadcasting Corporation's IRIS Telidon trial-the last in Canada - ended in March 1984, and the CBC has no plans for a service. In the United States, the NBC service ceased in January 1985, and the CBS "Extravision" service was maintained at a trace level.

\section{THE END OF TELIDON}

Why did Telidon fail? How did it get as far as it did, as fast as it did, and fade as soon as it did?

Customary explanations include human fallibility, private sector competitiveness and bureaucratic rigidity. The marketing research into consumer demand may have been inadequate. The videotex and teletext trials may have been on too small a scale for predictive reliability. The research is still in progress. Many individuals and organizations avidly accepted DOC encouragement, funding and publicity for $\mathrm{R}$ and $\mathrm{D}$, including my own polytechnic where in 1982-83 I was Project Director of a Telidon Public Initiatives Program for database development. Expectations for Telidon were high, in business, in academe and especially in government. The media were in full technofuture cry. It is no exaggeration to say that the telecommunications marketplace in Canada was gripped by Telidon fever from late 1979 to late 1982. Hope and belief 
displaced analysis and reason: hope and belief in technology-science-based technology - as an agent of change, a bringer of novelty, and enhancer of life. After all, there was a revolution taking place-the communications revolution. So we were told.

\section{Communications Technology in Society}

I have already described how media have been charged with and given the responsibility for the shaping of our cultural lives. Marshall McLuhan, despite his disclaimers that he did not prescribe but describe in his media probings, must be seen, not least by Canadians, as a central iconic figure in blaming and crediting communications technology for all manner of societal good and ill. But he was not alone. There were other powerful voices. The Clyne Commission concluded that telecommunications would

"form the infrastructure of the new industrial society that is now coming into being around the world. No person can totally understand this new society...but it is not too much to say that its birth is an event equal in importance to the Industrial Revolution of the 19th century. What is happening now in telecommunications will set the terms of life in the 21 st century just as surely as what happened in the 19th century industrialism set the terms of life for the 20th century" (Clyne, 1979:12).

The rhetoric includes active rather than passive verbs and an organic metaphor of birth. Technology as nature instead of artefact continues: "In the early 1970s federal and provincial governments became perhaps dimly aware...that the potential for effective policies was being carried away on a rapidly flowing river of technological development; today the ominous sound of the rapids ahead can be distinctly heard" (Clyne, 1979:5). Man is seen as powerless in the face of technology acting autonomously, as if it were a force of nature.

Two DOC staff, writing in 1980 on the information revolution, warn that "like the industrial revolution, the information revolution is unavoidable" (Serafini and Andrieu, 1981:13). They go on to point out that the "technological imperative" must also be borne in mind as a contributor to the information revolution (Serafini and Andrieu, 1981:27).

The examination of these attitudes which follows is carried out by a review of the most significant literature, along with appropriate exemplification from the Telidon case.

\section{The Technological Imperative}

Langdon Winner defines the notion of the technological imperative invoked above: "technologies are structures whose conditions of operation demand the restructuring of their environment" (Winner, 1977:100). He continues, 
Technological imperatives appear in public deliberations as generalized 'needs' or 'requirements'-for example, the need for an increasing supply of electrical power-which justify the maintenance and extension of highly costly sociotechnical networks... One can assume that each of the technologies in question-systems of communication [emphasis added], energy supply, transportation, industrial production-was originally founded upon some widely accepted purpose: the accomplishment of a particular goal or the continuous supply of a product or service. But the means to the end, the system itself, requires its own means: the resources, freedom and social power to continue its own work (Winner, 1977:258-9).

Again, for this notion to have operational value, it must be credited with a life of its own. To talk of a technological imperative is to give oneself the right to relinquish control over technology and technological change.

\section{Technological Determinism, Telidon and the Department of Communications}

The case can be made that the DOC acted in this period as if its existence were determined by Telidon, as if the Department existed to serve Telidon. The basis of this claim is not financial (budgets or person-years allocated), or administrative (briefs, reports or memoranda), but it is what may be called an impressionistic content analysis of announcements, press releases, speeches, brochures, conference presentations and media reports which issued from the DOC in proleptic profusion between 1978 and 1983. In their various guises, they proclaimed Telidon the benign acme of an interactive utopia. The media were avid in their competition to predict the next electronic enhancement of daily life. The rhetoric was that of technological determinism.

Why is technological determinism an issue here? From the standpoint of technological determinism, technological progress is seen as an automatic process which obeys immanent laws and technology is seen as autonomousout of control by human agency. The link between discovery in science, invention in technics and innovation in society seems automatic.

The notion of technological determinism "stands or falls on two hypotheses: a) that the technical base of a society is the fundamental condition affecting all patterns of social existence, and b) that changes in technology are the single most important source of change in society" (Winner, 1977:76).

Technological determinism in its many expressions is embodied in our language, culture and society. It is a daily practical deterrent to effective thought and action about technology. It reaches into every level of society, from consumer decisions to corporate planning, from individual citizens to government policy-makers. It makes individuals feel helpless in the face of an increasing range of new communications technologies. It allows corporations to invoke the 
myth of their commitment to experimental science and machine technology to perpetuate their existence and to legitimize their claims to public service. It encourages governments to welcome specific technical devices or systems as forms of order, and to embrace those technologies or systems which are compatible with particular kinds of political relationships. In this setting they may deal with the wrong kinds of political concerns, or avoid them completely (Morris, 1977). I suggest that the DOC's approach to Telidon must be considered in the light of this kind of analysis.

A popular formulation of this notion is that no one can resist "progress" and, indeed, who would wish to oppose such a personal and social good? A scholarly formulation was Robert L. Heilbroner's "Do Machines Make History?" (Heilbroner, 1967).

Reinhard Rurup digs deeply into the many layers of convention, ignorance, myth and concealment in which the topic is commonly wrapped (Rurup, 1974: 161-93).

Faced with an extraordinary acceleration in the pace of technological development, we feel more or less helpless... [T] oday we note a certain anxiety in industrial capitalist societies that technological development could become so automatic and self-perpetuating that, while perhaps remaining predictable, it would no longer be controllable. Mankind's great hope-that emancipation from the constraints of nature through technology would culminate in man's self-determination and emancipation as a socially and politically mature being-appears to be dashed-by history. Modern technology has increasingly proved to be a system-stabilizing force, not merely one capable of revolutionizing social conditions. And it appears to be slipping more and more out of human control, becoming an independent force that holds sway over our lives and world.

For these reasons, theoretical discussion about the relationship between technology and society has in the last few years ceased to revolve around questions about the meaning, nature, and 'cultural value' of technology... Today's discussion is concerned, instead, with the decisive question of whether and to what extent one can speak of the 'autonomy' in technology and, resulting from this, whether and to what extent all other spheres of life are necessarily dependent on technology; furthermore, whether technology has developed from a means to an end in itself, the 'naturally lawful' development of which could only be halted by a total social catastrophe.

Rurup goes on to quote Hans Freyer's warning of the danger of "exalting the 'immanent tendency of technology toward perfection' into something utopian in dimensions" because " "progress progresses-in terms of intensity, tempo, and capability to excite'." According to Freyer this attitude towards 
technology gives rise to a state of affairs in which " "the perfection of technological means is becoming the central topic, and the concrete progress that represents its promise is becoming the motive spirit of a whole era" (Rurup, 1974:162-3). Freyer's assessment could be applied directly to the public image of Telidon.

Another view of this philosophical stance on the nature of technology and its processes is provided by Stanley R. Carpenter (Carpenter, 1978:93-9). He is referring to Hans Jonas' characterization of modern technology:

1. Each new technological step is disequilibriating. This fact is both expected and encouraged by modem technological societies.

2. Every technological invention, like every new scientific insight, is expected to spread both in terms of knowledge and in practical adoption.

3. The relationship of means to ends is not unilateral but dialectical.

4. Progress, not to be equated with mere change, is an inbom drive with later stages considered superior to former ones, and within the concept of progress, it is possible to differentiate descriptive and normative components.

Jonas describes his push-pull model of modern technology.

The push comes from pressures of competition, population growth or resources depletion... the technological pull consists of the vision of an ever-better life and a belief that there can be indefinite progress, novelty, and inventive discovery. Identification of technological potential virtually ensures its realization.

In addition, "technology as a grand venture tends to establish itself as the transcendent end" (Carpenter, 1978:97). He says that technology "has exceeded the constraints of its origins and has developed a logic and dynamic of its own" and "appears to possess a univocal dynamic and contributes to a kind of alienation independent of ownership relations" (Carpenter, 1978:99).

Still relying on Rurup, we can now begin to move towards the possibility of an active instead of a passive response to technology. He presents the counterdeterministic views of Jurgen Habermas on this issue, that

the direction, functions, and pace of technological progress are still determined by societal interests which make themselves felt in investments, the public and private funding of research, and in the establishment of priorities. He contends that technological progress, far from being an automaton with social effects that can only be endured, is still the product of both conscious and unconscious decisions. This however means that not accommodation, but rather information and 
responsible action based on social planning is the order of the day (Rurup, 1974:165).

This counter-deterministic social planning was scarcely evident in the convergent thinking around Telidon: technological change is seen to bring its own plans with it.

The brilliance of Habermas' thought and the pertinence of his political prescriptions commend him to further consideration. Writing on "Dogmatism, Reason, and Decision: On Theory and Praxis in Our Scientific Civilization," he says,

in industrially advanced society, research, technology, production, and administration have coalesced into a system which cannot be surveyed as a whole, but in which they are functionally interdependent. This has literally become the basis of our life. We are related to it in a peculiar manner, at the same time intimate and yet estranged. On the one hand, we are bound externally to this basis by a network of organizations and a chain of consumer goods; on the other hand, this basis is shut off from our knowledge, and even more from our reflection. The paradox of this state of affairs will, of course, only be recognized by a theory oriented toward praxis, even though this paradox is so evident: the more the growth and change of society are determined by the most extreme rationality of processes of research, subject to a division of labour, the less rooted is this civilization, now rendered scientific, in the knowledge and conscience of its citizens. In this discrepancy, scientifically guided techniques and those of decision theory-and ultimately even cybernetically controlled techniques-encounter a limitation which they cannot overcome; this can be altered only by a change in the state of consciousness itself, by the practical effect of a theory which does not improve the manipulation of things and of reifications, but which instead advances the interest of reason in human adulthood, in the autonomy of action and in the liberation from dogmatism. This it achieves by means of the penetrating ideas of a persistent clique (Habermas, 1974:255-6).

As hopeful as this recommendation of a rational clique sounds, it also points to the presence of research, technological production and administrative cliques in our society. Pragmatically one acknowledges the soundness of this analysis, and sees these cliques around Telidon, within the system Habermas posits.

Two Canadian scholars at work on Canadian cultural analysis as economic history and political economy, following the directions charted by Harold Innis, offer these comments on how technological determinism develops and how it may be avoided. 
The commitment to technology must be distinguished from the relinquishment of control over technology. It lies within our power to direct the process of invention and to mediate the social consequences of technological change... Technological determinism is fostered, albeit unintentionally, by those who merely cultivate apprehension in the name of the old moral absolutes of the individual conscience or who remain utopian with regard to the machine (Rotstein and Watkins, 1972).

The former Director of the Harvard University Program on Technology and Society (in operation from 1964 to 1972) writes about containing the negative effects of technology.

The kinds and magnitudes of the negative effects of technology are no more independent of the institutional structures and cultural attitudes of society than is realization of the new opportunities that technology offers. With few exceptions, technologies in our society are developed and applied as a result of individual decision. Individual entrepreneurs, individual firms and individual government agencies are always on the lookout for technological opportunities: either new machines to reduce the cost of production, or new mechanical products to sell, or new technological systems to facilitate accomplishment of a mission (Mesthene, 1970:38).

Langdon Winner's Autonomous Technology provides the broadest base from which to approach the range of possibilities of technological impact on man and his culture. He means by autonomous technology "a general label for all conceptions and observations to the effect that technology is somehow out of control by human agency" (Winner, 1977:15). He is clearly not content with a term as simple as "technological determinism" and refers in addition to technological evolution, technological drift, the technological imperative, the victory of technique, technocracy, artifice and order, apraxia, technological politics and reverse adaptation. Clearly such a wide-ranging approach does not lend itself to a ready precis. Suffice it to say that the potential for guidance it offers for technological analysis, planning and policy-making and countervailing against technological determinism is substantial.

\section{CONCLUSION}

In summary, and in the light of the foregoing review of the issue, it may be seen on the one hand that the forward advance of Telidon was made possible by the work of scientists, engineers and technicians, but also by their belief in what the work was: technological change, therefore progress, and so a good in itself. As in most actions based on belief, the rational gave way to the emotional and the moral. The myth of an autonomous or deterministic technology prevailed; belief in the myth necessarily generates among the believers an ideological structure 
to allow and provide for implementational expression in a variety of ways, times and levels.

To research this issue is difficult, if not impossible. Our liberal, voluntarist culture leads to the denial of deterministic practice, or even its possibility, by those at the ideological interface. Pragmatics may be the answer. Let us observe the next revolutionary telecommunications innovation-high-definition television (HDTV) - for signs of its deterministic embrace of those responsible for its care, feeding and development. It is abundantly clear that HDTV is already being treated as deterministically as was Telidon.

\section{EPILOGUE}

At this writing in the Fall of 1989 we learn that a new broadcasting act in on its way to Parliament. This deserves our careful attention for the possibility of immanent deterministic philosophy. We may have been given a clue by the present Minister of Communications. Talking about the nature of the telecommunications market, he said that "our infrastructure must be adapted to the technological and industrial imperatives of a changing world" (Masse, 1989). (Emphasis added.) The terminology is reiterated; the cast of mind prevails.

\section{ENDNOTES}

1. An earlier version of this paper was presented at the Seventh International Conference on Culture and Communication of the Institute of Culture and Communication, Temple University, Philadelphia, Pennsylvania in October 1989.

2. For my part, I wrote three papers for the Department of Communications:

a) June 1981; revised June 1982, Culture, Communications and Media: A Research Theme in Technology and Society in Canada.

b) August 1981; revised June 1982, Technological Determinism: Its Place in the Work of the New Services and Social Policy Division, Department of Communications.

c) August 1981; revised June 1982, Technology Assessment.

3. IRIS: Information Relayed Instantly from the Source.

\section{REFERENCES}

Bown, H.G., C.D. O'Brien, W. Sawchuk and J.R. Storey. 1978. A General Description of Telidon: A Canadian Proposal for Videotex Systems. CRC Technical Note No. 697-E. Ottawa: CRC, Department of Communications. 
Carpenter, Stanley R. 1978. Developments in the Philosophy of Technology in America. Technology and Culture 19: 1.93-99.

Clyne, Hon. J.V., Chairman, Consultative Committee on the Implications of Telecommunications for Canadian Sovereignty. 1979. Telecommunications and Canada, 1-2;5. Ottawa: Minister of Supply and Services Canada.

Ferguson, Stewart, and Sherry Devereaux Ferguson. 1980. Cultural Policy Priorities Scaling, 4. Paper given at the Annual Conference of the Canadian Communication Association.

Foote, John. June 1980. Communication and Culture 3;4;8;1;2 Ottawa: Broadcasting and Social Policy Branch, Department of Communications.

Fox, the Honorable Francis. 1981. Notes for an address to the Annual Meeting of the Canadian Cable Television Association, 16. Quebec City, 1981:05:12.

Habermas, Jurgen. 1974. Theory and Practice, 255-6. London: Heinemann Educational Books Ltd.

Heilbroner, Robert L. 1967. Do Machines Make History?. Technology and Culture 8(3).

Juneau, Pierre, Deputy Minister of Communications. 1981. National Information Technology in the Global Marketplace. Notes for an address to the Annual General Meeting of the Canadian Advanced Technology Association, Ottawa, 1981:04:29.

Masse, the Honourable Marcel, Minister of Communications. 1989. Notes for an address on telecommunications and technology at the opening of the Canadian Satellite Users' Conference, Ottawa, 1989:06:19.

Mesthene, Emmanuel G. 1970. Technological Change: Its Impact on Man and Society, 38. Cambridge, Mass.: Harvard University Press.

Morris, Bertram. 1977. The Context of Technology. Technology and Culture $18(3)$.

Ostry, Bernard, formerly Deputy Minister of Communications. 1986. At a meeting of the Canadian Chapter of the Intemational Institute of Communications, Montreal, 1986:11:28.

Plowright, Teresa. 1980. Social Aspects of Videotex Services: Proposed Policy Directions. Ottawa: Social and New Services Policy Division, Broadcasting and Social Policy Branch, Department of Communications. 
Rotstein, Abraham, and Melville H. Watkins. 1972. The Outer Man: Technology and Alienation. In J.L. Granatstein and Peter Stevens, eds., Forum: Canadian Life and Letters 1920-70. Toronto: University of Toronto Press.

Rurup, Reinhard. 1974. Historians and Modern Technology: Reflections on the Development and Current Problems of the History of Technology. Technology and Culture, 15(2): 161-93.

Serafini, Shirley, and Michel Andrieu. 1981. The Information Revolution and its Implications for Canada, 13;27. Communications Economics Branch, Department of Communications. Ottawa: Minister of Supply and Services Canada.

Winner, Langdon. 1977. Autonomous Technology: Technics-out-of-Control as a Theme in Political Thought, 100;258-9;76;15. Cambridge, Mass., and London: MIT Press. 